\title{
A CONSIDERATION OF ETHICAL AND LEGAL ISSUES IN MULTI-SITE STUDIES
}

\author{
Sana Loue*
}

\begin{abstract}
Significant ethical and legal issues may arise in conjunction with the conduct of multi-site studies. For example, different cultures may have varying concepts of personhood. The United States, for instance, places significant emphasis on the autonomy of each individual, while many other societies rely to a greater degree on defining an individual with reference to his or her roles or relationships to others. These differing orientations may have implications for informed consent procedures and for the design of procedures to maintain confidentiality of the data and privacy of the participants. The development of procedures for the maintenance of confidentiality and privacy must also consider any differences in reporting requirements between the sites that relate to sexually transmitted diseases and child abuse. The implications of such differences for the conduct of multi-site studies are examined.
\end{abstract}

Key Words: Multi-site studies, confidentiality

\section{CONSIDERACIÓN DE LOS TEMAS ÉTICOS Y LEGALES EN LOS ESTUDIOS MULTICÉNTRICOS}

Resumen: En relación con los estudios multicéntricos pueden surgir aspectos éticos y legales. Por ejemplo, culturas diferentes tienen conceptos distintos sobre las personas. Así, Estados Unidos enfatiza la autonomía del individuo, mientras que otras sociedades definen, en mayor grado, al individuo según sus roles o su relación con los demás. Estas orientaciones diferentes pueden influir en el proceso de obtener consentimiento informado y en el diseño de procedimientos para mantener la confidencialidad de los datos y la privacidad de los participantes. El desarrollo de procedimientos que garanticen la confidencialidad y la privacidad debe considerar, también, cualquiera diferencia entre los centros al informar los requisitos que tengan relación con enfermedades de transmisión sexual y con abuso de niños. Se examinan las inferencias de estas diferencias al realizar estudios multicéntricos.

Palabras clave: Estudios multicéntricos, confidencialidad

\section{CONSIDERAÇÃO DOS TEMAS ÉTICOS E LEGAIS NOS ESTUDOS MULTICÊNTRICOS}

Resumo: Nos estudos multicêntricos surgem questões éticas e legais. Por exemplo, culturas diferentes tem conceitos distintos sobre as pessoas. Assim, nos Estados Unidos enfatiza-se a autonomia do indivíduo, enquanto que em outras sociedades definem, em maior ou menor grau, o indivíduo segundo seus papéis e sua relação com os demais. Essas diferentes orientações podem influir no processo de obtenção do consentimento informado e no desenho de procedimentos para manter a confidencialidade dos dados e a privacidade dos participantes. O desenvolvimento de procedimentos que garantem a confidencialidade e a privacidade deve levar em conta, também, qualquer diferença entre os centros ao informar os requisitos que tenham relação com as enfermidades de transmissão sexual e com abuso de crianças. As interferências destas diferenças nos estudos multicêntricos são analisadas.

Palavras chave: Estudos multicêntricos, confidencialidade

J.D., Ph.D., M.P.H. Associate Professor Case Western Reserve University, School of Medicine, Department of Epidemiology and Biostatistics.

Correspondence: SXL54@po.cwru.edu 


\section{Introduction}

In order to ensure that results are valid across the various sites of a multi-site study, it is important that, to the greatest extent possible, procedures across all sites be identical. This includes not only any interventions that may be part of the study, but recruitment and consent procedures as well. The 2002 revision of CIOMS' International Ethical Guidelines for Biomedical Research Involving Human Subjects ${ }^{1}$ explains in a commentary to Guideline 4 the parameters of the informed consent process:

"Obtaining informed consent is a process that is begun when initial contact is made with a prospective subject and continues throughout the course of the study. By informing the prospective subjects, by repetition and explanation, by answering their questions as they arise, and by ensuring that each individual understands each procedure, investigators elicit their informed consent and in so doing manifest respect for their dignity and autonomy. Each individual must be given as much time as is needed to reach a decision, including time for consultation with family members or others. Adequate time and resources should be set aside for informed-consent procedures."

As part of this process, investigators must provide to participants during the informed consent process information about any limits to their ability to protect the confidentiality of the data to be collected and the potential consequences of any breach of that confidentiality (Guideline 5).

This article reviews issues related to the preservation of confidentiality and the use of certificates of confidentiality that may arise in the context of multi-site studies.

Council of International Organizations of Medical Sciences. International Ethical Guidelines for Biomedical Research Involving Human Subjects. Geneva: CIOMS; 2002.

\section{Certificates of Confidentiality}

Numerous mechanisms exist for safeguarding study data once it has been collected. These include, for instance, omitting information that might reveal the identity of the participant and limiting access to information by using passwords on computers, keys for filing cabinets and offices. In the United States, certificates of confidentiality may also be available to limit external access to study data. However, because similar mechanisms may not exist in jurisdictions outside of the United States, legal and ethical issues related to the maintenance of confidentiality may arise.

Certificates of confidentiality are issued by the National Institutes of Health to protect the confidentiality of research data by protecting investigators and institutions from being compelled to release information about the study participants. Authority for the issuance of certificates of confidentiality arises from section 301(d) of the Public Health Service Act, which provides that the Secretary of Health and $\mathrm{Hu}-$ man Services may authorize individuals engaged in biomedical, behavioral, clinical, or other research to protect the privacy of individuals who are the subjects of that research. This authority has been delegated to the National Institutes of Health.

A certificate of confidentiality, as indicated, allows researchers to avoid the involuntary disclosure of data that could identify either directly or indirectly an individual, such as through a court order. "Identifying characteristics" refers to such things as name, address, social security number, fingerprints, voiceprints, photographs, and genetic information such as DNA. If a certificate of confidentiality is obtained, the study participants must be told of this. However, the fact that there is a certificate in place to protect confidentiality may not be used to coerce individuals to participate in the study. 
The certificate does not protect against voluntary disclosures by the investigator, such as in cases of child abuse, reportable sexually transmitted diseases, and the disclosure of information pursuant to audit requirements by the funding entity. If the investigator wishes to retain the ability to disclose voluntarily such things as child abuse, he or she must advise the participant of this in the informed consent documents. The certificate still allows the participant to consent to the disclosure of specified information, if he or she wishes to do so.

A certificate of confidentiality is available only for research that is considered to be sensitive. This includes research that involves the collection of information related to genetics; the psychological well-being of individuals; sexual attitudes, preferences, and behaviors; substance abuse and other illegal behaviors; and exposures that may be the focus of litigation, such as pesticide exposures. Sensitive information could be defined as information that could damage an individual if it were to be released or could result in discrimination or stigmatization of that individual in his or her community. One example is that of research on the transmission of HIV and other sexually transmitted disease.

Certificates can be issued for single site projects and for multi-site projects as well. In order to obtain a certificate for a multi-site study, each participating unit, together with its address and the name of its director, must be indicated. The lead site of a multi-site study must indicate that it has a copy of the approval of the study and the consent form from the institutional review board at each site. NIH funding for the project is not required in order to obtain a certificate.

Some types of projects are not eligible for a certificate of confidentiality. This includes projects that are not research, projects that do not include the collection of personally identi- fying information, projects that have not been reviewed and approved by an institutional review board as required by the guidelines for certificates, and projects that are collecting information that, if disclosed, would not significantly harm or damage the individual to whom the information pertains.

In order to apply for a certificate of confidentiality, the investigator must provide the following information to the appropriate institute of the National Institutes of Health: the name and address of the research institution, the title of the research project, the sites where the research is to be conducted, the source and number of the supporting grant, documentation of approval from the appropriate institutional review board or boards and the qualifications of these boards, the contact information for the principal investigator and other key personnel, a summary of the scientific training of all key personnel, the beginning and ending dates of the research, a description of the research and the study procedures, a description of means used to protect the participants' identity, the reasons for requesting a certificate of confidentiality, and copies of the informed consent forms approved by the appropriate institutional review boards. In addition, the applicant investigator and the appropriate official from his or her institution must sign a letter containing prescribed verbiage that indicates that the investigator and institution will defend the certificate against any legal attack if challenged.

Consider the following examples of studies in which the protections of a certificate of confidentiality might be important.

- An HIV-vaccine trial is being conducted in several countries. As part of the study, the investigators must collect data on sexual behavior. In one of the countries in which the study is being conducted, homosexuality is stigmatizing, but is not illegal. In a 
second country, homosexuality is illegal and may result in imprisonment. In the third country site, homosexuals have almost the same legal rights as heterosexuals.

- A study is investigating an intervention to reduce the transmission of sexually transmitted diseases among women who are at high risk. Commercial sex workers are enrolled into the study. In one country, prostitution is legal if the individual is registered and has a permit. However, all instances of sexually transmitted diseases must be reported to the licensing authority, which will then revoke the permit. Anecdotal reports indicate that those reported to be infected with HIV have been killed by individuals in the community, although information relating to their permits is supposed to remain confidential. At the second site, in another country, commercial sex work is illegal and those engaged as commercial sex workers are subject to imprisonment and potentially face the loss of their children.

- A study is investigating the genetic causes of schizophrenia. At one site, individuals are able to obtain medical care through a socialized medical system. Consequently, they will not experience a loss of care due to a diagnosis of schizophrenia, but may be socially stigmatized. In contrast, at the second site, individuals are able to access their choice of care based upon their ability to pay, which often depends on whether or not they have private health care insurance. They could potentially be disqualified from receiving insurance benefits if they were found to be genetically susceptible to chronic disease, such as schizophrenia.

Several critical issues are raised if certificates of confidentiality or a similar mechanism to protect the confidentiality of the data and the privacy of the participants are not available across all sites of a study. First, how does the availability of these protections differentially impact recruitment and retention across all sites? Second, does the existence of these protections at some, but not all, of the participating sites in a multisite study result in significant variation of the risk-benefit ratio across the sites and, if it does, how can this be remedied?

The answer to the first question is, at the present time, unknown. No studies have been conducted on what participants understand about certificates of confidentiality or how the existence of a certificate might influence their decision to participate in a study. It is possible, for instance, that the existence of a certificate and the apparently heightened confidentiality protections would not carry any significance for the participants. However, the possession of a certificate and its additional protections may be critical to recruitment and retention efforts in instances where participants are particularly vulnerable due to a potentially stigmatizing characteristic or illegal behavior. Research relating to the impact of certificates of confidentiality would help to clarify this issue and may, in fact, be critical to understand if the risk-benefit ratio varies across sites.

The answer to the second question is unclear. In order for the risk-benefit ratio to be different as a result of the certificate of confidentiality, the certificate must actually be effective in precluding access to information that would identify an individual study participant. Even in the United States, where the certificates are available and in use, their present effectiveness is unclear. In 1973, a New York State appeals court upheld the refusal of a substance use program director to provide, as ordered by a court, identifying information about program participants ${ }^{2}$. The program director refused to produce the requested information based on assurances from

People v. Newman, 32 N.Y. 2d 379 (1973). 
then-existing federal Department of Health and Welfare that the data had a guarantee of absolute confidentiality pursuant to the then-existing statutes ${ }^{3,4}$. These statutes provided that the Secretary of the Department of Health and Welfare and the United States Attorney General were empowered to authorize persons "engaged in research on the use and effect of drugs" to "protect the privacy of [the research participants]" by withholding their "names or other identifying characteristics" from anyone not associated with the research program ${ }^{5}$. Such authorized persons could not "be compelled in any Federal, State, or other local, civil, criminal, administrative, legislative or other proceedings" to identify the research participants ${ }^{6}$. The appeals court held that federal law regarding the confidentiality of these data preempted any state provisions that might permit access. Whether the courts today would also uphold the use of the certificate of confidentiality to preclude access to identifying characteristics is unclear, in view of subsequent changes in the statutory language and the enactment of other laws that might reflect competing interests, such as laws aimed at the identification of individuals believed to be associated with terrorist efforts.

Realistically, the risk-benefit ratio may vary for groups of participants by virtue of the differing conditions across study sites, regardless of the existence of a certificate of confidentiality. For example, individuals who do not have access to health care outside of the context of a research study may perceive more benefits to their participation than those at a different site, who have access to health care routinely due to the nature of the health care infrastructure. Consistency in the study protocol across all sites cannot be interpreted to necessitate consistency in all circumstances. Unlike the situation involving health care, however, reliance on a certificate of confidentiality represents a variation in the actual study procedures and protections.

Assuming that the certificate would be upheld and that a resulting difference in the riskbenefit ratio must be addressed, several potential solutions may be available. First, it may be possible to negotiate, in the context of specific studies, an agreement between the study sites and concerned legal and administrative entities to provide confidentiality protection to the same degree that would be provided as if there were a certificate of confidentiality in place. This would entail fairly complex negotiations involving multiple entities and would provide protection only for the specified study or studies.

A second, broader approach would require the development of an agreement between the country or countries sponsoring the research and the sites at which the research is to occur. This approach would require cooperation and collaboration at multiple levels of government, in addition to any institutional agreements. Each of these potential approaches, however, will require considerable examination and negotiation. 